\title{
Teaching Practices and Student Motivation that Influence Student Achievement on Large-Scale Assessments
}

Gul Shahzad Sarwar ${ }^{*}$, Carlos Zerpa ${ }^{1}$, Krystal Hachey ${ }^{2}$, Marielle Simon $^{3}$, \& Christina van Barneveld ${ }^{4}$

\author{
${ }^{1}$ Faculty of Education, University of Lakehead, 955 Oliver Road, Thunder Bay, Canada \\ E-mail: czerpa@lakeheadu.ca \\ ${ }^{2}$ Faculty of Education, University of Ottawa, 145 Jean-Jacques Lussier, Ottawa, Canada \\ E-mail:khach026@gmail.com \\ ${ }^{3}$ Faculty of Education, University of Ottawa, 145 Jean-Jacques Lussier, Ottawa, Canada \\ E-mail: msimon@uottawa.ca \\ ${ }^{4}$ Faculty of Education, University of Lakehead, 955 Oliver Road, Thunder Bay, Canada \\ E-mail: cvanbarn@lakeheadu.ca
}

*Corresponding author: Gul Shahzad Sarwar, Faculty of Education, University of Ottawa, 145 Jean-Jacques Lussier, Ottawa, Canada

Tel: 1-613-562-5804_E-mail: gsarw065@uottawa.ca

Received: July 10, 2012 Accepted: August 12, 2012 Published: September 2, 2012 doi:10.5296/ije.v4i3.2087 URL: http://dx.doi.org/10.5296/ije.v4i3.2087 


\begin{abstract}
The purpose of this study was to identify the effect of teaching practices and student motivation on student achievement in mathematics. Two principal component analyses (PCA) were conducted. The first PCA was conducted to cluster 22 items related to teaching practices, in which the items were selected from a teacher questionnaire. The second PCA was conducted to cluster 11 items related to student motivation, in which the items were selected from a student questionnaire. Results from the first PCA revealed that the extraction of four components was found to be related to several frameworks found in the literature on teaching strategies. For the second PCA, two components were extracted which were related to student motivation. These extracted components were then used as two sets of independent variables in a hierarchical regression analysis in order to study their impact on student achievement in mathematics. The study revealed that four teaching practice components and the two student motivation components were significantly related to student academic achievement in mathematics on the large-scale assessment.
\end{abstract}

Keywords: teaching practices; student motivation; student achievement; mathematics teaching; large-scale assessment 


\section{Introduction}

One particular issue related to large-scale assessments is student motivation (Roderick \& Engel, 2001). When students are motivated to provide optimal performance during large-scale assessments, their estimated abilities more closely reflect their true abilities. Teachers, however, have reported that students are not necessarily motivated to provide optimal performance during large-scale assessments (van Barneveld, King, Simon, \& Nadon, 2010). Student motivation to achieve on large-scale assessments may be an indication of overall willingness to achieve at school. Among a variety of school-related factors, teaching practices, particularly those centered on the learner, have been shown to impact student motivation whether in the classroom or during large-scale assessments (Kelley, Heneman, \& Milanowski, 2000; McCombs \& Whisler, 1997; Ryan, Ryan, Arbuthnot, \& Samuels, 2007) and education reforms often aim to adopt the most promising, evidence-based teaching practices that can motivate students.

If teaching practices have influence on student motivation, which is a mediating factor on achievement, it follows then that educational leaders should be interested in regularly investigating current teaching approaches and their relationship with motivation and achievement on large-scale assessments. One way to accomplish this is by asking relevant questions on the teacher questionnaires. Although many of the international large-scale assessments already question teachers on such practices, their framework may not necessarily be grounded in the literature or may not have been updated to consider many of the reforms that have been proposed in the last twenty years, particularly in the field of Mathematics.

The purpose of this study was twofold. The first purpose was to provide empirical evidence on the relationship among teacher practices, student motivation, and student achievement on a large-scale assessment in Grade 9 Mathematics. The second purpose was to examine the extent to which teaching practices, found in the literature and surveyed in a teacher questionnaire, aligned with those said to motivate students and improve their learning outcomes in mathematics. The two research questions that guided the study were:

1) To what extent does student motivation, inferred from the student background questionnaire, predict student achievement on a large-scale assessment of mathematics?

2) Do teaching practices, as reported in the teacher questionnaire, make a significant contribution to the student achievement over and above the contribution from student motivation?

\section{Literature Review}

In order to better understand the complex relationship among the concepts of teaching practices, student motivation and student achievement in the context of current large-scale assessments in Mathematics, we review the literature on student motivation, particularly from the expectancy-value theory, on learner-centered teaching practices, on reforms in Mathematics education, and on the relationship among these variables. The section ends with a review of the literature on how teacher background questionnaires for large-scale assessment are conceptualized and grounded, particularly in relation to teaching practices that motivate student learning. 


\subsection{Student Motivation}

Motivation theories address an individual's reason for learning and the conditions under which motivation is maximized (Ames, 1992; Covington \& Mueller, 2001). Ryan et al. (2007) presented a detailed review of the theoretical and empirical literature on motivation constructs and processes that have a role in students' motivation on large-scale assessments. The constructs and processes included students' achievement goals, values, self-concept, self-efficacy, text anxiety and cognitive processes. A prominent example of a theory associated with student motivation and that combines such constructs and processes, is the expectancy-value theory (Atkinson, 1964; Eccles et al., 1983). Expectancy-value theory, developed by Eccles et al. (1983), postulates that an individual's choice, persistence, and performance is influenced by the individual's expectancy-related and task-value beliefs (Eccles \& Wigfield, 2002; Wigfield \& Cambria, 2010). Expectancy-related beliefs refer to individuals' views about how well they will perform on an upcoming task, either in the immediate or longer-term future (Eccles \& Wigfield, 2002). According to Eccles et al. (1983) task-value beliefs are shaped by four major components: 1) Attainment value or importance; 2) Intrinsic or interest value; 3) Utility value or usefulness of task; and 4) Cost. Attainment value is the level of importance of success an individual attributes to, while intrinsic or interest value is the enjoyment an individual experiences by doing the task. Utility value means how the individual sees his or her future benefitting from completing the task, and cost is related to what the individual has to contribute to complete the task including the amount of effort required to complete the task. Examples of task-specific beliefs that influence task-expectancies and task-value include perceptions of the difficulty of the task, perceptions of the individual's ability to complete the task, individuals' goals and self-schema (Eccles \& Wigfield, 2002).

In the context of large-scale assessments and according to the expectancy-value theory, a student's beliefs affect both the value he or she assigns to content, process and outcomes of the assessment, and his or her views about succeeding on the assessment. This in turn affects the student's behavior during large-scale assessments. This two-component student motivation framework was supported by Zerpa, Hachey, van Barneveld, and Simon (2011) in the context of large-scale assessments. Zerpa et al. argued that students' task-values and effort are significant predictors of their academic achievement on a large-scale assessment. When a student values the outcome of the large-scale assessment, there is a greater likelihood that the student will be personally motivated and makes a conscious effort to engage with the tasks to the best of his or her ability (Eccles \& Wigfield, 2002; Ryan et al., 2007).

\subsection{Learner-Centered Teaching Practices}

An approach to teaching, called learner-centered practices, is consistent with expectancy- value theory's construct of expectancy-related belief. As the term suggests, when teachers adopt learner-centered practices, they focus on the students' needs, interests, skills, and learning styles. Teacher-centered or program-centered practices, on the other hand, align mainly with teaching objectives or the need to cover the program. Specific educational practices emphasized by learner-centered practices encourage the learners to create a personal 
representation of knowledge by constructing it over a period of time (McCombs \& Whisler, 1997). For this goal to be accomplished, teachers provide various ways in which students can link previous knowledge to newly acquired knowledge. Learner-centered practices may be categorized in term of five dimensions: a) meta-cognitive and cognitive; b) affective; c) developmental; d) personal and social; and e) individual differences (McCombs \& Whisler, 1997). The meta-cognitive domain refers to "the process of 'thinking about thinking' which is accomplished through self-awareness, self-inquiry, dialogue or self-monitoring" (Presidential Task Force, 1993, p. 9). The affective domain involves the roles of engagement, attaching meaning, beliefs and emotions in learning. Developmental factors address the unique physical, intellectual, emotional and social development of each student. The personal and social aspects highlight the importance of interpersonal interactions. The individual differences among students describe the influence of their different capabilities and preferences on their learning and achievement.

There is evidence to support the assumption that learner-centered practices produce positive results on student learning outcomes (Allonge, 2011; Lam \& Law, 2007; McCombs \& Whisler, 1997; Rossi, 2009; Tole, 2010; Wijnia, Loyens, \& Derous, 2011). Teaching practices that offer meaningful tasks, collaboration, and feedback focusing on individual improvement increase intrinsic motivation in students (Pintrich, 2003). According to McCombs and Whisler (1997), learners placed in this type of environment have a better understanding of what to expect and what exercise choices and control will be implemented. Students feel challenged and engaged in interesting and relevant activities. They perceive that they have the competence to succeed and feel respected as individuals with different needs and preferences. McCombs and Whisler (1997) further suggest that educational systems must embrace a learner-centered classroom practice to maximize high standards of learning, motivation, and achievement for all learners.

\subsection{Mathematics Education Reform}

A mathematics reform that supports learner-centered principles and practices among other changes to dominant mathematics teaching practices was initiated in 1980. The National Council of Teachers of Mathematics (NCTM) published a document called An Agenda for Action (Tate, 1994) to influence the way teachers think about teaching mathematics. The main characteristics of the educational practices, recommended by the mathematics reform, are found in the NCTM policy documents from the years 1989, 1991, and 2000 (Ross, Hogaboam-Gray, \& McDougal, 2002). These practices include having a broader scope of mathematics that cover multiple math strands without focusing solely on numeration and operations, ensuring that all students have access to all forms of math; assigning tasks that are complex, open-ended, and apply to real-life situations; constructing mathematical ideas through discussion rather than transmitting mathematics through lecturing; encouraging the use of manipulative and other learning tools; encouraging student-to-student interaction; implementing assessments that are authentic; drawing on diverse abilities with a relevance to everyday life; and focusing equally on building students' confidence as well as building students' math abilities (Ross et al., 2002). According to the reform, mathematics is dynamic and not fixed, such that the role of the teacher in a math reform classroom is similar 
to a mathematics community leader who learns along with the students as opposed to being the sole knowledge expert (Ross et al., 2002).

In general, the mathematics reform challenges the 'drill and practice' approach of mathematics lessons and presents a more interactive classroom where mathematics is seen as a creative process involving extending, inventing, reflection, and debating (Schifter, 1996). In relation to teacher practices, the mathematics reform literature suggests that teachers focus on process rather than on a set of specific tasks and provide consistent feedback instead of a single grade (Stipek, Givvin, Salmon, \& MacGyvers, 2001). There is also an emphasis to stress student learning and growth instead of whether they have answered questions as right or wrong (Stipek et al., 2001). The mathematics classroom, according to the mathematics reform, is seen as a space of discovery (Schifter, 1996).

\subsection{Relationship among Student Motivation, Learner-Centered Teaching Practices, Mathematics Education Reform and Student Achievement on Large-Scale Assessments}

The literature on expectancy-value theory, learner-centered teaching practices, and mathematics education reform provides the necessary basis for exploring how teacher practices and student motivation influence student achievement in mathematics. Table 1 compares several frameworks found in the literature on teaching strategies, student characteristics and achievement in various disciplines such as Language and Sciences, but with a focus on Mathematics. It links specific teaching activities associated with various learning dimensions. A look across authors suggests that the development of students' autonomy seems to contribute to achieving greater motivation. The use of scaffolding and the promotion of students' self-confidence are teaching strategies that target personal or individual differences. Building a sense of community among students is a learner-directed strategy that also has been shown to have a positive relationship with motivation. Presentation of meaningful, real-life activities address the students' affective dimension whereas bringing students to think critically, open-ended questions, and challenging work develops the meta-cognitive dimension. The use of constructive assessment and the provision of individual feedback are teaching strategies that target assessment and feedback dimension.

Stipek et al. (2001) examined the convergence between mathematics reform literature, student motivation, and how they both relate to student achievement in mathematics. They looked at five specific teaching objectives recommended by both the mathematics reform and research on motivation. These teaching objectives were aimed at encouraging students to: a) learn for understanding, rather than to get correct answers; b) have higher self-confidence in their mathematics abilities; c) take risks with more difficult tasks; and d) enjoy mathematics. The findings from that study suggest that the following teaching practices are associated with motivation and learning: a) providing constructive feedback, b) emphasizing effort, risk-taking, learning, and understanding, and c) providing opportunities for autonomy.

Based on the mathematics reform literature, Pantziara and Philippou (2007) identified six structures of instructional practices that influence motivation in mathematics. These structures are: a) task; b) instructional aids; c) practices towards the task; d) affective sensitivity; e) messages to students; and f) recognition. They were used in their observational 
protocol in their study on motivational and effective teaching practices. Tasks referred to specific activities such as problem solving, algorithms or using open/closed questions. Use of visual aids to connect students' new knowledge with old knowledge was recorded as an example of instructional aids. Instructional category of practice towards the task included asking for solution plans or asking about reasons for mathematical choices instead of focusing on correct answers. Affective sensitivity referred to the demonstration of enthusiasm towards math or the demonstration of sensitivity towards students themselves. Communicating that errors are part of the learning process was an example of messages to students. Examples of recognition included commenting on student progress or final outcome. Pantziara and Philippou (2007) found that tasks, specifically problem solving and open questioning; instructional aids, specifically visual aids, and connecting new and old knowledge; practices towards task, specifically encouraging understanding and explaining misconceptions; and recognition and affective sensitivity, as contributors to a generally warm classroom environment, are related to student motivation and achievement.

Table 1. Comparison of learner-centered strategies associated with five learning dimensions across various authors

\begin{tabular}{|c|c|c|c|c|c|}
\hline \multirow[b]{2}{*}{$\begin{array}{l}\text { Authors (year } \\
\text { of publication) }\end{array}$} & \multicolumn{5}{|c|}{ Learning dimensions } \\
\hline & $\begin{array}{l}\text { Personal } \\
\text { (Individual } \\
\text { differences) }\end{array}$ & Social & $\begin{array}{l}\text { Affective/ } \\
\text { engagement }\end{array}$ & $\begin{array}{l}\text { Cognitive and } \\
\text { Meta-cognitive }\end{array}$ & $\begin{array}{l}\text { Assessment and } \\
\text { feedback }\end{array}$ \\
\hline $\begin{array}{l}\text { Matteson et al. } \\
(2001)\end{array}$ & $\begin{array}{l}\text { Involvement of } \\
\text { students }\end{array}$ & Group work & Kinesthetic activities & - & - \\
\hline Lam \& Law (2007) & - & - & $\begin{array}{l}\text { Real-life (relevant) } \\
\text { tasks }\end{array}$ & Stimulate curiosity & Feedback \\
\hline Tole (2010) & - & $\begin{array}{l}\text { Interactive } \\
\text { activities }\end{array}$ & Fun activities & $\begin{array}{l}\text { Direct instruction } \\
\text { with student } \\
\text { participation }\end{array}$ & Review for tests \\
\hline Alonge (2011) & & Group work & Hands-on activities & - & - \\
\hline Wijnia et al. (2011) & Scaffolding & Collaboration & Meaningful tasks & Challenging tasks & Positive feedback \\
\hline Stipek et al. (2001) & $\begin{array}{l}\text { Self-confidence; } \\
\text { Enjoy } \\
\text { mathematics }\end{array}$ & - & Risk-taking & $\begin{array}{l}\text { Emphasizing learning } \\
\text { and understanding }\end{array}$ & $\begin{array}{l}\text { Providing } \\
\text { constructive } \\
\text { feedback }\end{array}$ \\
\hline Ames (1992) & $\begin{array}{l}\text { Recognition of } \\
\text { effort and } \\
\text { mistakes }\end{array}$ & Grouping & - & - & Feedback \\
\hline $\begin{array}{l}\text { Pantziara \& } \\
\text { Philippou (2007) }\end{array}$ & - & - & $\begin{array}{l}\text { Warm environment; } \\
\text { Affective sensitivity }\end{array}$ & $\begin{array}{l}\text { Pressing students for } \\
\text { understanding; Use of } \\
\text { open-ended questions }\end{array}$ & $\begin{array}{l}\text { Practice towards } \\
\text { tasks; Recognition } \\
\text { of errors }\end{array}$ \\
\hline Friesen (2009) & - & $\begin{array}{l}\text { Sense of } \\
\text { community }\end{array}$ & $\begin{array}{l}\text { Thoughtful design to } \\
\text { engage students; Work } \\
\text { is worth their time and } \\
\text { attention }\end{array}$ & $\begin{array}{l}\text { Work that requires } \\
\text { students to think } \\
\text { critically }\end{array}$ & Assessment \\
\hline
\end{tabular}


In her grounded theory study on teaching strategies and their role on student motivation in high school Mathematics classes, Tole (2010) indicated that a combination of direct instruction and learner-centered approaches was needed to motivate students. She suggests that direct instruction, interactive activities, independent practices, fun activities and review for tests are key practices that favor student motivation. These seem to align, to some extent, with McCombs and Whisler's (1997) five learning dimensions.

Friesen (2009) examined the convergence between effective teaching practices, student motivation, and how they both relate to student achievement in today's classroom. Friesen looked at teaching objectives recommended by research on motivation. These teaching objectives were aimed at encouraging a student to: a) learn for conceptual understanding, rather than for getting correct answers; b) have higher self-confidence in their abilities; c) take risks with more difficult tasks; and d) feel pleasure and excitement in learning. The findings from Friesen's (2009) study suggested that the following effective teaching practices framework is associated with student motivation and learning: 1) the inclusion of a thoughtful design of learning to engage students intellectually and academically; 2) the work students are asked to undertake is worth their time and attention and require students to think critically; 3) the inclusion of assessment practices to improve student learning and guide teaching methodology; 4) teachers should promote a sense of community among students; and 5) teachers should improve their practice by consulting their peers and through professional learning.

The studies presented in Table 1 feature various methodological designs such as quasiexperimental designs (e.g., Lam \& Law, 2007; Wijnia et al., 2011) and grounded studies (e.g., Tole, 2010); take various formats such as theses (e.g., Alonge, 2011; Tole, 2010) and technical reports or conference papers (e.g., Friesen, 2009; Pantziara \& Philippou, 2007); and deal with various subject matters such as writing (e.g., Matteson et al., 2001) and Mathematics (e.g., Stipek et al., 2001). Although individually, the studies do not perfectly coincide with each other, together, they offer support for five common dimensions. These include teaching practices that foster the personal (individual differences), social (group work), affective (meaningful tasks and challenges), and cognitive/metacognitive (problem solving) learning dimensions as well as the use of a constructive assessment, or more specifically, feedback whereby students learn from their mistakes.

\section{Method}

In this section we present the data sources of our study and the processes used to select items from the teacher and student questionnaires. We also describe the principal component analysis applied to the data from both the teacher and student questionnaires.

\subsection{Data Sources and Populations}

Every year, the Educational Quality and Accountability Office (EQAO), Ontario, Canada administers a province-wide assessment to all students enrolled in Grade 9 Mathematics. Apart from having students complete the achievement tests, EQAO requires teachers and students to fill out background questionnaires. Although most background questionnaires are not developed based on an established and academically grounded 
conceptual framework, the EQAO teacher background questionnaire for Grade 9 Mathematics is appealing because, unlike other large-scale assessments, it features a variety of teaching and assessment practices and instructional aids for teaching mathematics. The data used in this study were thus the results of EQAO's 2010 administration of the Grade 9 large-scale assessment of mathematics. Three data sets were used: a) teacher responses to the teacher questionnaire items, b) student responses to the student questionnaire items, and c) students' scores on the mathematics achievement tests. These three data sets were respectively labeled as teaching practices, student motivation, and student achievement. The data were collected from 790 schools. The total number of teacher participants was 6,373. All cases with missing data were listwise deleted, which resulted in the inclusion of 4,501 (or $71 \%$ ) teachers for data analysis. The listwise deletion procedure (in which all data records are excluded where any variable value is missing) is a feasible option and produces unbiased estimates when data items are missing completely at random and the sample size is large (Basilevsky, Sabourin, Hum, \& Anderson, 1985; Roth \& Switzer, 1995; Witta, 1992).

The EQAO teacher questionnaire data file and student questionnaire data file were merged by two common columns named "ClassID" and "Program/AppliedOrAcademic" using Microsoft SQL Server 2008. This enabled the current study to have student data corresponding to the teacher data. The merged file contained 106,124 students' records corresponding to 4,501 teachers' records. There was a one-to-many relationship between teacher and student data, therefore, the means of items related to the student data were taken within the individual teacher level. All cases with missing data were listwise deleted, which resulted in a total sample of 92,976 (or $88 \%$ ) students for data analysis corresponding to the 4,428 teachers in the merged file. These teachers and students completed the questionnaires using Likert-type scales to answer about their practices and motivation respectively.

\subsection{Teacher and Student Questionnaire Items}

One of the purposes of the teacher and student questionnaires was to encourage them to report, on a Likert-type scale, their perception about the experience related to mathematics teaching and learning. The teacher questionnaire contained a total of 181 questions, 32 of which asked teachers about their teaching practices and their professional development activities. These 32 questions were grouped into following three main questions and were selected for the analysis:

1) This past semester or year, how often did you have your Grade 9 mathematics students do each of the following? a) discuss and use problem-solving strategies for finding answers (e.g., work backward, use a chart, make a model); b) use concrete materials to investigate and understand new concepts; c) solve open-ended problems; d) work collaboratively to solve problems; e) discuss mathematical ideas and relationships; f) conduct mathematical investigations (e.g., to demonstrate the inquiry process); g) explain the reasoning behind their answers; h) write solutions using mathematical language and symbols; i) demonstrate a mathematical process to other students (e.g., a presentation to the class or a small group); j) use the Internet to find secondary data.

2) How often did you have your Grade 9 mathematics students engage in activities related to 
the following achievement categories? a) knowledge and understanding; b) thinking; c) communication; d) application.

3) This past semester or year, how often did you use the following tools and strategies in assessing your Grade 9 students' progress in mathematics? a) observation notes or checklists; b) meetings with individual students; c) observations of students applying mathematical concepts to authentic real-life contexts; d) dated work samples (portfolios); e) small diagnostic paper-and-pencil tests; f) tests; g) quizzes; h) investigations of mathematical concepts; i) mathematics journals; j) results of work done on the computer; k) demonstrations of mental mathematics ability and estimation; 1) self-assessment; m) peer-assessment; n) solution of open-ended questions; o) student presentations to other students; p) construction of physical or concrete models; q) rubrics related to achievement chart, r) results of work done on a graphing calculator.

The student questionnaire contained a total of 27 questions and 11 of them focused on student motivation in mathematics. As one of the purposes of the study was to link student motivation with student achievement in mathematics, all 11 questions were selected for the analysis. The questions were: a) I like math; b) I am good in math; c) I understand most of the mathematics I am taught; d) the mathematics I learn now is very useful for everyday life; e) I need to keep taking mathematics for the kind of job I want after I leave school; f) mathematics is boring; g) mathematics is an easy subject; h) how much time do you usually spend on mathematics homework (in or out of school) on any given day; i) how often do you complete all of your mathematics homework; j) how often have you been absent from your Grade 9 mathematics class this year; k) how often have you been late for your Grade 9 mathematics class this year?

\subsection{Data Screening}

We conducted a principal component analysis (PCA) of the selected questions from the teacher and student questionnaires using SPSS version 20. The data for teacher and student questionnaires were checked separately for appropriateness of the PCA by generating a correlation matrix of each data set (with several correlations in the matrix greater than 0.30 in both the data sets). The Kaiser-Meyer-Olkin (KMO) measure of sampling adequacy value was 0.89 and 0.86 respectively for teacher and student questionnaires. Bartlett's test of sphericity (Field, 2005) showed a significant value of $p=0.00$ for both teacher and student questionnaires.

There were 107 outliers in the teacher questionnaire data and 57 in the student questionnaire data. These outliers were identified by computing the factor score variables in the principal component analysis with a value greater than \pm 3.0 . These cases were omitted from the data and the analysis was redone. As there was no change in the pattern of component loadings and communalities, outliers did not have an effect on the final analysis. As these outliers did not change the results, they were included in the final analysis.

\subsection{Principal Component Analysis for Teacher Questionnaire}

PCA with a varimax rotation (Kim \& Mueller, 1978) was conducted on the 32 teacher questionnaire items related to teacher practices. The analysis was conducted in six iterations by 
repeating the PCA procedure to reach a satisfactory solution. After each iteration, commonalities and component loadings were reviewed and only those items with communalities greater than 0.5 were included in subsequent iterations (Field, 2005). The outcome included 22 out of the 32 items. As for the remaining items, seven had commonalities less than 0.5 and three had factor loadings less than \pm 0.5 or factor loadings greater than \pm 0.5 on more than one component. They were thus removed from subsequent iterations.

Table 2. Components Loadings for the PCA of the Teacher Questionnaire

\begin{tabular}{|c|c|c|c|c|}
\hline \multirow[b]{2}{*}{ Items } & \multicolumn{4}{|c|}{ Teaching practices that foster student motivation } \\
\hline & Social & $\begin{array}{l}\text { Affective/ } \\
\text { engagement }\end{array}$ & $\begin{array}{c}\text { Cognitive \& } \\
\text { meta-cognitiv } \\
\text { e }\end{array}$ & $\begin{array}{l}\text { Assessment } \\
\& \text { feedback }\end{array}$ \\
\hline \multicolumn{5}{|l|}{$\begin{array}{l}\text { This past semester or year, how often did you } \\
\text { have your Grade } 9 \text { mathematics students do each } \\
\text { of the following? }\end{array}$} \\
\hline $\begin{array}{l}\text { Discuss and use problem-solving strategies for } \\
\text { finding answers }\end{array}$ & 0.67 & 0.18 & -0.01 & 0.20 \\
\hline Work collaboratively to solve problems & 0.66 & 0.04 & 0.07 & 0.27 \\
\hline Discuss mathematical ideas and relationships & 0.77 & 0.15 & 0.09 & 0.04 \\
\hline $\begin{array}{l}\text { Demonstrate a mathematical process to other } \\
\text { students }\end{array}$ & 0.56 & 0.02 & 0.10 & 0.40 \\
\hline $\begin{array}{l}\text { Use concrete materials to investigate and } \\
\text { understand new concepts }\end{array}$ & 0.39 & 0.87 & -0.01 & 0.36 \\
\hline Solve open-ended problems & 0.17 & 0.75 & 0.04 & 0.34 \\
\hline Conduct mathematical investigations & 0.17 & 0.51 & 0.07 & 0.37 \\
\hline Explain the reasoning behind their answers & 0.29 & 0.88 & 0.09 & -0.02 \\
\hline $\begin{array}{l}\text { Write solutions using mathematical language and } \\
\text { symbols }\end{array}$ & 0.27 & 0.55 & 0.12 & -0.21 \\
\hline Use the Internet to find secondary data & -0.05 & 0.72 & 0.03 & 0.18 \\
\hline \multicolumn{5}{|l|}{$\begin{array}{l}\text { How often did you have your Grade } 9 \text { mathematics } \\
\text { students engage in activities related to the } \\
\text { following achievement categories? }\end{array}$} \\
\hline Knowledge and Understanding & 0.15 & 0.21 & 0.77 & -0.05 \\
\hline Thinking & 0.25 & 0.05 & 0.77 & 0.18 \\
\hline Communication & 0.24 & 0.05 & 0.82 & 0.17 \\
\hline \multicolumn{5}{|l|}{$\begin{array}{l}\text { This past semester or year, how often did you use } \\
\text { the following tools and strategies in assessing } \\
\text { your Grade } 9 \text { students' progress in mathematics? }\end{array}$} \\
\hline Observation notes or checklists & 0.04 & 0.07 & 0.01 & 0.61 \\
\hline Dated work samples (portfolios) & 0.10 & 0.01 & 0.18 & 0.64 \\
\hline Small diagnostic paper-and-pencil tests & 0.07 & 0.20 & -0.08 & 0.88 \\
\hline Tests & 0.09 & 0.08 & 0.25 & 0.54 \\
\hline Quizzes & 0.00 & 0.02 & -0.05 & 0.64 \\
\hline Results of work done on the computer & 0.23 & 0.01 & 0.15 & 0.61 \\
\hline Self-assessment & 0.16 & -0.06 & 0.17 & 0.66 \\
\hline Peer-assessment & 0.13 & 0.17 & -0.10 & 0.53 \\
\hline Rubrics related to the achievement charts & 0.04 & 0.07 & 0.01 & 0.61 \\
\hline
\end{tabular}

The PCA clustered 22 items around four components. These four components had eigenvalues greater than 1 and represented $66.4 \%$ of the total variance of the 22 items. In social sciences, this amount of variance is generally regarded as satisfactory (Hair, Black, Babin, Anderson, \& Tatham, 2006). The research team interpreted the resulting four components as essentially corresponding to four of the five effective teaching practices 
dimensions presented in the Table 1 with the exception of the 'personal' dimension as none of the items from the teaching questionnaire clustered around this dimension. The individual dimensions for effective teaching practices framework that corresponds to extracted components in the PCA are listed in Table 2. This correlation was an attempt to represent a coherent model of effective teaching practices framework so that the resulting four extracted components could relate to the theoretical models already presented. This attempt at correlating extracted model with theory provided us with a tool to analyze and locate effectiveness of certain teaching practices in the context of large-scale assessment.

All the items included in the analysis were measured with a 5-point Likert-type scale labeled as Very often, Often, Sometimes, Seldom, and Never. Many researchers (Cronbach, 1950; Komorita, 1963; Matell \& Jacoby, 1971; Peabody, 1962) contend that a Likert-type scale measure primarily an attitude or direction, and only marginally intensity. Moreover, the reliability and validity of the Likert scale does not depend on the number of scale intervals (Percy, 1976). Matell and Jacoby (1971) also obtained similar results when higher ordered scales were collapsed. Therefore, for the purpose of simplicity in reporting response frequency results, the 5-point Likert-type scale of 22 items was collapsed into three: Often, Sometimes, and Never.

Table 3. Scales, Reliabilities, Number of Items loading on a Component, Keywords from the Items and Mean Response Frequencies of Items loading on Component

\begin{tabular}{|c|c|c|c|c|c|c|}
\hline \multirow{2}{*}{$\begin{array}{l}\text { Scale/ } \\
\text { Component }\end{array}$} & \multirow{2}{*}{$\begin{array}{l}\text { Cronbach's } \\
\text { alpha }\end{array}$} & \multirow{2}{*}{$\begin{array}{l}\text { No. of items } \\
\text { loading on a } \\
\text { component }\end{array}$} & \multirow{2}{*}{ Keywords from the items } & \multicolumn{3}{|c|}{$\begin{array}{c}\text { Mean response frequencies of } \\
\text { Items loading on component }(\%)\end{array}$} \\
\hline & & & & Often & Sometimes & Never \\
\hline Social & .83 & 4 & $\begin{array}{l}\text { Discuss problems; work collaboratively; } \\
\text { discuss ideas and relationship }\end{array}$ & 40.82 & 49.21 & 9.97 \\
\hline $\begin{array}{l}\text { Affective/ } \\
\text { engagement }\end{array}$ & .83 & 6 & $\begin{array}{l}\text { Use concrete material; solve open-ended } \\
\text { problems; mathematical investigations; } \\
\text { explain the reasoning; mathematical language; } \\
\text { use Internet }\end{array}$ & 67.80 & 16.86 & 15.34 \\
\hline $\begin{array}{l}\text { Cognitive and } \\
\text { meta-cognitive }\end{array}$ & .87 & 3 & $\begin{array}{l}\text { Knowledge; understanding; thinking; } \\
\text { communication }\end{array}$ & 75.84 & 22.51 & 1.65 \\
\hline $\begin{array}{l}\text { Assessment } \\
\text { and feedback }\end{array}$ & .76 & 9 & $\begin{array}{l}\text { Observation; checklist; portfolios; rubric, } \\
\text { paper-and-pencil tests; quizzes, } \\
\text { self-assessment; peer-assessment }\end{array}$ & 57.62 & 38.80 & 3.58 \\
\hline
\end{tabular}

A summated scale was constructed for each of the four components by taking the arithmetic mean of all of the related items with high loadings (equal to or greater than 0.5 ) on a component. The four scale scores were used for the next analysis instead of the original items. A specific benefit of the summated scale is that it can provide a researcher the option to represent multiple aspects of a concept in a single measure (Hair et al., 2006). To verify that 
items forming the summated scale were measuring similar entities and had sufficient internal consistency, Cronbach's alpha was computed. Table 3 shows the reliability of each summated scale expressed in Cronbach's alpha. The table also represents mean response frequencies of items loaded on four components, the number of items loading on a component and keywords from the items loaded on a component.

\subsection{Principal Component Analysis for Student Questionnaire}

The procedure for PCA, adopted for the teacher questionnaire, was also used for the student questionnaire. Two items (i.e., mathematics is boring; and how often do you complete all of your mathematics homework?) were reverse coded in this analysis. A PCA was administered first to determine the total number of components which could be extracted from the students' EQAO questionnaire data. The Kaiser-Guttman criterion to extract components having eigenvalues greater than 1 yielded three components. After inspecting the scree plot and earlier research done by Zerpa et al. (2011), in which they extracted two components from the 2007 EQAO student questionnaire data, it was decided to extract two components using a varimax rotation. The first component was related to the importance of mathematics in daily life, whereas the second component was related to the amount of effort a student put into the subject. Therefore, these two components were interpreted by the research team as the task-values and effort in mathematics by using the expectancy-value theory framework and previous research done by Zerpa et al. (2011). The proportion of variance explained by these two components was $68.83 \%$. Table 4 displays the final output of the PCA and component loadings of the student questionnaire on the two components.

Table 4. Components Loadings for the PCA of the Student Questionnaire

\begin{tabular}{|c|c|c|}
\hline \multirow{2}{*}{ Items } & \multicolumn{2}{|c|}{ Components } \\
\hline & Task-values & Effort \\
\hline I like math. & .80 & .19 \\
\hline I am good in math. & .83 & .01 \\
\hline I understand most of the mathematics I am taught. & .78 & .05 \\
\hline The mathematics I learn now is very useful for everyday life. & .51 & .28 \\
\hline I need to keep taking mathematics for the kind of job I want after I leave school & .50 & .26 \\
\hline Mathematics is boring. & .54 & .30 \\
\hline Mathematics is an easy subject. & .79 & -.15 \\
\hline $\begin{array}{l}\text { How much time do you usually spend on mathematics homework (in or out of } \\
\text { school) on any given day? }\end{array}$ & -.06 & .65 \\
\hline How often do you complete all of your mathematics homework? & .27 & .62 \\
\hline How often have you been absent from your Grade 9 mathematics class this year? & .07 & .55 \\
\hline How often have you been late for your Grade 9 mathematics class this year? & .10 & 63 \\
\hline
\end{tabular}

Note. Items with a component loading equal to or higher than 0.5 were considered to have high loading (Hair et al., 2006).

Two summated scales were constructed by taking the arithmetic mean of all of the related items with high loadings (equal to or greater than 0.5 ) on a component. These summated scales were used for a further analysis to represent student motivation. The coefficient of internal consistency reliability, as measured by the Cronbach's alpha values, 
was 0.85 for the "task-values" component and 0.72 for the "effort" component.

\section{Results}

To determine the effects of teacher practices and student motivation on overall student achievement in mathematics, a hierarchical regression was conducted. The two components/ scales related to student motivation and the four components/scales related to teaching practices were included in the research design as independent variables in a particular order. The two student motivation components (i.e., task-value and effort) were entered into the equation at the first level. The four components related to teacher practices were entered at the second level over and above the two components constructed from the student questionnaire. At the second level, student motivation was controlled to check for the effect of teacher practices on student overall achievement. Table 5 presents the descriptive statistics and Pearson correlations of a dependent variable of overall achievement level and the six components included in the study.

Table 5. Pearson Correlations, Means and Standard Deviations for all Variables $(n=4,428)$

\begin{tabular}{lccccccc}
\hline Variables/Components & X1 & X2 & X3 & X4 & X5 & X6 & X7 \\
\hline X1. Overall Achievement Level & - & & & & & & \\
X2. Task-value & .33 & - & & & & & \\
X3. Effort & .40 & .36 & - & & & & \\
X4. Social & .06 & $.11^{*}$ & .13 & - & & & \\
X5. Affective/engagement & .52 & .09 & .07 & .27 & - & & \\
X6. Cognitive and meta-cognitive & .13 & .08 & .14 & .42 & .34 & - & \\
X7. Assessment and feedback & .41 & .13 & .27 & -.23 & .43 & .47 & - \\
Mean & 2.68 & 2.72 & 2.50 & 3.69 & 3.43 & 4.10 & 2.81 \\
Standard Deviation & 0.52 & 0.61 & 0.49 & 0.63 & 0.52 & 0.49 & 0.53 \\
\hline
\end{tabular}

Note. ${ }^{*} p=.11$; for all other correlations $p<.001$.

Results of the hierarchical regression suggest that the proportion of variance in student overall achievement (dependent variable) accounted for by the two components from student motivation (first level) was $28 \%$. It was found that this change in the amount of variance accounted for in the dependent variable, from 0 to $28 \%$, gives $F(2,4425)=624.87$, was significant $(p=.00)$. This shows that at the first level, the two student motivation components were positive predictors of student overall achievement. However, when the four components from teacher practices were added to the model (second level), $R^{2}$ increased to $67 \%$. Therefore, teacher practices accounted for an extra $39 \%$ of the variance in student overall achievement. It was shown that $39 \%$ change in the amount of variance from the first level to the second level gives $F(6,4421)=27.04$, which was again significant $(p=.00)$. The change statistics therefore indicate that the four teacher practice components significantly predicted overall student achievement over and above the two student motivation components $\left(\Delta R^{2}=0.39\right)$. 
In the current study, a frequency analysis of teacher questionnaire data showed that, to improve student achievements, about $40.82 \%$ of the teachers often ask students to work collaboratively and to discuss their strategies. While students are involved in these intellectual activities, they communicate with the teacher and their peers. During the discussions, teachers encourage students to share ideas and their relationships in the context of problem solving. As a result of this encouragement, the students collectively conduct mathematical investigations and demonstrate their inquiry process to each other.

To deliver high quality instruction, teachers need to know both mathematics and how children learn (Marshall, 2006). As such, teachers should design classroom tasks for their students that are fully engaging and worth their time and attention. High quality instruction and lesson plans are what a student expects at school. While designing such classroom tasks, the result of this study suggested that $67.80 \%$ of responding teachers often used concrete materials to make students understand new concepts; they ask students to explain reasoning behind their answers to give students conceptual knowledge. This outcome tends to indicate that these teachers understand that conceptual knowledge enhances students' ability to solve new problems and provides a deeper insight into a problem. In addition, 75.84\% of teachers engage students in cognitive and meta-cognitive activities related to knowledge, thinking and understanding of the principles of mathematics. Such thoughtful design of learning fosters a sense of continuous learning among students.

Teachers also use variety of instruments for formative and summative assessment as a means of identifying learning targets (Taras, 2008) and to give specific feedback to their students (Sadler, 1989). Higher quality learning depends upon a constant self- and peer-assessment. Students cannot change their understanding unless they are aware of their own position and of the goal they want to achieve. Self-assessment gives them a tool to overview their position, in relation to the goals they want to achieve. Peer-assessment is particularly important in the context of group work. The results of the current study show that $57.62 \%$ of participating teachers often conduct formative and summative assessment using different assessment instruments. Roderick and Engel (2001) argue that the degree of collective responsibility for learning, that teachers create in the classroom and convey to their students, is the mechanism through which motivation translates into substantive work effort. Helping students to get motivated towards learning, helping them in achieving their goal, and conducting activities in a classroom, which are meaningful to all students, seem to be essential to success of a student.

\section{Discussion}

The study examined the impact of both teaching practices and student motivation on student academic achievement in mathematics on a large-scale assessment. It is difficult to understand student motivation without understanding the context. Teacher and student questionnaires analyzed in this study provided a glimpse of that context from the viewpoint of the teachers as well as the students. The results of the PCA, using the student questionnaire, revealed two student motivation components, which were interpreted as task-value and effort (Wigfield \& Cambria, 2010). These two components were related to expectancy-value theory 
and are important to understand the achievement of a student in the context of a large-scale assessment (Ryan et al., 2007).

The four teaching practices components were found to correspond to four of the five learning dimensions presented in Table 1. Although it was found in the literature that the dimension labeled as 'personal' also predicts student motivation and achievement (Mattheson et al., 2001; Stipek et al, 2001), particularly when teaching practices support the development of learner autonomy, the data did not support it. One reason may be that the specific teacher questionnaire, examined in this study, does not directly ask questions on the concept of learner autonomy. The items 'meeting with individual students' and 'use of mathematic journals', may address such practices but they contributed to none of the four dimensions statistically identified. Furthermore, in this specific context, the concept of autonomy may be integrated within the affective/engagement dimension. Given its importance in the literature, however, consideration should be given to the addition of specific items regarding teaching practices that foster learner autonomy.

The results suggest that all the independent variables considered in this research predict, to some extent, student achievement on a large-scale assessment. A comparison of the $R^{2}$ at the first level and its change at the second level and a significant $p$ value associated with the transition from first level to second level suggests that the prediction power at the second level improves as compared to the first level with the addition of four components of teaching practices over and above the two components of student motivation. These four components related to teaching practices are likely to influence student achievement more than student motivation components and add to the predictability of the model at the second level. Overall, student achievement is significantly related to student motivation and is also significantly related to teacher practices after controlling for student motivation. Two previous researchers independently found that student motivation is strongly related to student achievement performance (Wigfield \& Eccles, 2000) and that teacher practices affect student mathematics learning and academic achievement (Ball \& Rowan, 2004). This study provides evidence that the effect of teacher practices and student motivation can be combined to positively affect student achievement on large-scale assessments, particularly in mathematics.

The exploratory nature of the study can serve as the basis for the development of a research program in this area. The four variable framework could be used to help structure and formulate a concise list of items targeting teaching practices known to impact achievement. These could be empirically tested and statistically examined within various disciplines and with students at the primary and secondary levels for refinement and validation purposes.

One of the limitations of the current study was that the data included responses of teachers and students of Ontario, Canada only. Therefore, it might be difficult to determine its degree of validity for the teachers from other geographical regions or educational jurisdictions. These teachers taught the subject of mathematics at the high school level. Data collected from the teachers teaching different subjects or at different grades might produce different results. This study, however, can be considered as an exploratory study which can 
serve as the basis for other similar studies. Another limitation is that the current study used a secondary analysis of data. Therefore, any pre-test of students' academic achievements to assess the effects of the teaching practices, were not able to be conducted. With such large province-wide data, it may also be possible that the students were not randomly assigned to teachers. It is very likely that higher-performing students had, on average, more effective teachers. This is likely because sometimes the more experienced teachers get assigned to the more advanced students, and teachers in schools serving more affluent (and typically higher achieving) students are likely to be relatively more experienced and effective than teachers in schools serving children from lower-income families. Additionally, the responses in both the teacher and student questionnaire were self-reported. The participants may interpret questions included in the questionnaires slightly differently and, therefore, may respond differently with the varied meanings. The frequency that some teachers would perceive to be "often" others might rate as "sometimes". The responses of the participants may also not coincide with their practices, but in the study there was no instrument to check their responses against their actual practices. For example, teachers may report more or less use of computers in their classrooms.

\section{Acknowledgement}

The research was financed by the Social Sciences and Humanities Research Council of Canada.

\section{References}

Alonge, H. B. (2011). Impact of activity and lab based teaching on student performance and motivation. Retrieved from ProQuest Dissertations \& Theses. (UMI 1498394)

Ames, C. (1992). Classrooms: Goals, structures, and student motivation. Journal of Educational Psychology, 84(3), 261-271.

Atkinson, J. W. (1964). An Introduction to Motivation. Princeton, NJ: Van Nostrand.

Ball, D. L., \& Rowan, B. (2004). Introduction: Measuring instruction. Elementary School Journal, 105(1), 3-10.

Basilvesky, A., Sabourin, D., Hum, D., \& Anderson, A. (1985). Missing data estimators in the general linear model: An evaluation of simulated data as an experimental design. Communications in Statistics, 14, 371-394.

Covington, M. V., \& Mueller, K. J. (2001). Intrinsic versus extrinsic motivation: An approach/avoidance reformulation. Educational Psychology Review, 13(2), 157-176.

Cronbach, L. J. (1950). Further evidence on response sets and test design. Educational and Psychological Measurement, 10, 3-31.

Eccles J. S., Adler, T. F., Futterman, R., Goff, S. B., Kaczala, C. M., Meece, J. L., \& Midgley, C. 
(1983). Expectancies, values, and academic behaviors. In J. T. Spence (Ed.), Achievement and Achievement Motivation (pp. 75-146). San Francisco, CA: W. H. Freeman.

Eccles, J. S., \& Wigfield, A. (2002). Motivational beliefs, values and goals. Annual Review of Psychology, 53, 109-132.

Field, A. P. (2005). Discovering statistics using SPSS (2 ${ }^{\text {nd }}$ ed.). London: Sage.

Friesen, S. (2009). Teaching effectiveness: A framework and rubric. Toronto, ON: Canadian Education Association.

Hair Jr., J. F., Black, W. C., Babin, B. J., Anderson, R. E., \& Tatham, R. L. (2006). Multivariate data analysis ( $6^{\text {th }}$ ed.). Upper Saddle River, NJ: Pearson Education Inc.

Kelley, C., Heneman, H., \& Milanowski, A. (2000). School-based performance award programs, teacher motivation, and school performance: Findings from a study of three programs (CPRE Research Report RR-44). Philadelphia, PA: Consortium for Policy Research in Education.

Kim, J., \& Mueller, C. W. (1978). Introduction to factor analysis: What it is and how to do it. Newbury Park, CA: Sage.

Komorita, S. S. (1963). Attitude content, intensity, and the neutral point on a Likert scale. Journal of Social Psychology, 61, 327-34.

Lam, S. F., \& Law, Y. K. (2007). The roles of instructional practices and motivation in writing performance. The Journal of Experimental Education, 75(2), 145-164.

Marshall, J. (2006). Math wars 2: It's the teaching, stupid! Phi Delta Kappan, 87(5), 356-363.

Matell, M. S., \& Jacoby, J. (1971). Is there an optimal number of alternatives for Likert scale items? Study I: Reliability and validity. Educational and Psychological Measurement, $31,657-74$.

Matteson, S. M., Swarthout, M. B., \& Zientek, L. R. (2011). Student motivation: Perspectives from Mathematics teachers. Action in Teacher Education, 33, 283-297.

McCombs, B. L., \& Whisler, J. S. (1997). The learner-centred classroom and school. San Francisco: Jossey-Bass.

Pantziara, M., \& Philippou, G. (2007). Students' motivation and achievement and teachers' practices in the classroom. In J. H. Woo, H. C. Lew, K. S. Park, \& D. Y. Seo (Eds.). Proceedings of the $31^{\text {st }}$ Conference of the International Group for the Psychology of Mathematics Education, Vol. 4, pp. 57-64. Seoul, Korea: PME.

Peabody, D. (1962). Two components in bipolar scales: Direction and extremeness. Psychological Review, 69, 65-73.

Percy, L. (1976). An argument in support of ordinary factor analysis of dichotomous variables, Volume 3. In B. B. Anderson (Ed.), Advances in Consumer Research (pp.143-148). Provo, UT: Association for Consumer Research. 
Presidential Task Force on Psychology in Education, American Psychological Association (1993, January). Learner-centred psychological principles: Guidelines for school redesign and reform. Washington, DC: American Psychological Association/ Mid-continent Regional Educational Laboratory.

Printrich, P. R. (2003). A motivational science perspective on the role of student motivation in learning and teaching contexts. Journal of Educational Psychology, 95, 667-686.

Roderick, M., \& Engel, M. (2001). The grasshopper and the ant: Motivational responses of low-achieving students to high-stakes testing. Educational Evaluation and Policy Analysis, 23(3), 197-227.

Ross, J., Hogaboam-Gray, A., \& McDougal, D. (2002). Research on reform in mathematics education, 1993-2000. Alberta Journal of Educational Research, 48(2), 122-130.

Rossi, C. M. (2009). A study of community college learner-centered teaching styles and students' motivation to learn. Retrieved from ProQuest Dissertations \& Theses. (UMI 3405442)

Roth, P. L., \& Switzer, F. S. (1995). A Monte Carlo analysis of missing data techniques in a HRM setting. Journal of Management, 21, 1003-1023.

Ryan, K. E., Ryan, A. M., Arbuthnot, K., \& Samuels, M. (2007). Students' motivation for standardized math exams. Educational Researcher, 36(1), 5-13.

Sadler, D. R. (1989). Formative assessment and the design of instructional systems. Instructional Science, 18(2), 145-65.

Schifter, D. (1996). A constructivist approach on teaching and learning mathematics. Phi Delta Kappan, 77(7), 492-499.

Stipek, D., Givvin, K., Salmon, J., \& MacGyvers, V. (2001). Teachers' beliefs and practices related to mathematics instruction. Teaching and Teacher Education, 17(2), 213-226.

Taras, M. (2008). Summative and formative assessment. Active Learning in Higher Education, 9(2), 172-192.

Tate, W. F. (1994). Mathematics standards and urban education: Is this the road to recovery?, The Educational Forum, 58(4), 380-390.

Tole, A. (2010). Effects of teaching strategies on student motivation to learn in high school mathematics classes. Retrieved from ProQuest Dissertations \& Theses. (UMI 3397899)

van Barneveld, C., King, S., Simon, M., \& Nadon, C. (2010). Final report on the analysis of teachers' responses to constructed-response questions on the Grade 9 assessment of mathematics teacher questionnaire, winter and spring 2010 administration. Toronto: EQAO, $31 \mathrm{p}$.

Wigfield, A., \& Cambria, J. (2010). Student's achievement values, goal orientations, and interest: Definitions, development, and relations to achievement outcomes. 
Developmental Review, 30(1), 1-35.

Wigfield, A., \& Eccles, J. S. (2000). Expectancy-value theory of achievement motivation. Contemporary Educational Psychology, 25, 68-81.

Wijnia, L., Loyens, S. M. M., \& Deroux, E. (2011). Investigating effects of problem-based versus lecture-based learning environments on student motivation. Contemporary Educational Psychology, 36, 101-113.

Witta, E. L. (1992). Seven methods of handling missing data using samples from a national database. (Unpublished doctoral dissertation). Virginia Polytechnic Institute and State University, Blacksburg, VA.

Zerpa, C., Hachey, K., van Barneveld, C., \& Simon, M. (2011). Modeling student motivation and students' ability estimates from a large-scale assessment of mathematics. Sage Open, 1(2), 1-9. http://dx.doi.org/10.1177/2158244011421803

\section{Copyright Disclaimer}

Copyright reserved by the author(s).

This article is an open-access article distributed under the terms and conditions of the Creative Commons Attribution license (http://creativecommons.org/licenses/by/3.0/). 